\title{
Breeding Ground Profile of Food Fish Species in Damodar River System
}

\author{
Lina Sarkar \& Samir Banerjee \\ Aquaculture Research Unit, Department of Zoology, University of Calcutta \\ 35 B C Road, Kolkata 700 019, India \\ E-mail: 1s1969@rediffmail.com
}

\begin{abstract}
Today unwise anthropogenic activity has disturbed the natural ecosystem globally. Civilization on its way to goal has destroyed nature as well as natural diversity. Aquatic ecosystem is also facing the same adverse effect as they are used as waste releasing source. However, anthropogenic activity has drastically damaged the natural habitat of all the living being. Though river water is used for agriculture, fisheries, residential and industrial developments, mining activity, navigation, power generation and variety of other activities including sand digging and disposal of industrial and domestic wastes, but still, some natural breeding do exists in the nature. Identification of those natural breeding ground and to bring them under proper conservation is a most effective way of natural breed conservation. The river Damodar is the most important watershed in the eastern part of India and is one of the main tributaries of the Ganga. The river housed a healthy fish faunal diversity in the recent past but today in spite of drastic deterioration of natural ecosystem, astonishingly no significant difference occurred in faunal composition of the river system.
\end{abstract}

Keywords: Breeding ground, Conservation, Hydrology

\section{Introduction}

The river Damodar is the most important watershed in the eastern part of India and is one of the main tributaries of the Ganga. This river is used for agriculture, fisheries, residential and industrial developments, mining activity, navigation, power generation and variety of other activities including sand digging and disposal of industrial and domestic wastes. It had a notable fishery status and fulfilled the demand of the fish eating people of West Bengal in the recent past (Banerjee, 1996).

The river Damodar originates from the hills of Chotonagpur in Jharkhand and drains into a fan shaped catchment area of about 25,820 sq km. The entire Damodar valley can be divided into the upper, middle and lower valleys according to the gradient (Hora, 1947; Job and Motwani, 1952). The undulating upper and the middle valleys are wider than the flat lower valley. The river has a total length of $540 \mathrm{~km}$, out of which $380 \mathrm{~km}$ is in Jharkhand and the next $160 \mathrm{~km}$ is in West Bengal. The river slope is $1.86 \mathrm{~m}$ per km for $241 \mathrm{~km}, 57 \mathrm{~m}$ per km in the next $167 \mathrm{~km}$ and $16 \mathrm{~m}$ per km in the last reach. In final $145 \mathrm{~km}$ the Damodar takes a southward course before joining the river Hooghly. The main tributaries of the river are the Barakar and the Konar. The Damodar was east flowing up to the year 1757 when it was out-falling into the extended bay, well north of present Kolkata. Around the year 1762, it took a sharp turn southwards somewhere in Burdwan and presently enters the Bay of Bengal far south of Kolkata. The upper and middle catchment area, constituting over $4 / 5^{\text {th }}$ of the total catchment area is a hilly terrain with a steep slope while the lower valley is strikingly narrow and flat. Thus, in the event of heavy rain in the upper valley, there is a natural tendency for water to overflow in the lower alluvial plain where most of the farm lands and human habitats are located. To cope up with the flood situation five dams have been constructed over the entire river system. The Tilayia dam was filled during 1953, the Konar during 1955, the Maithon in 1957, the Panchet during 1959 and the Durgapur in 1966. These dams as in case of other dams of the globe have affected the hydrological system of the river and altered the natural habitats of the river system. These changes, in turn, affected the fish population in the river stretch.

The Damodar is seasonal and flood prone mainly on account of reasons, which are physiographic and meteorological in nature. Frequent floods ravage the lower valley area, which is not only very fertile owing to its alluvial plain suitable for irrigation and agriculture but also used for various industrial activities. 


\section{Literature review}

Survey of international literature on river fish diversity, hydrology and ecology of rivers provides extensive data concerning the Ichthyofauna of river systems both in India and abroad (Matthews, et al.,1986, 1987, 1988a, 1994; Matthews, 1986b, 1987a, 1998; Sakar and Yadav, 1996; Poff, N.L., 1996, 1997; Chen et al., 2002; Steffy, 2003; Ahmed, 2004; Ahmed and Alfasana, 2004a; Anning, 2004; Ashfaque and Alfasana, 2004b; Garcia et al., 2004; Hauer and Habersack, 2005; Piazza et al., 2005).

Fish fauna of the Damodar along the stretch of $160 \mathrm{~km}$ from below Rajarappa upto Anderson Weir was reviewed by Job and Motwani (1952) before the construction of dams to understand the extent of the future adverse effects on the fish fauna after the construction of dams. Hora (1947) discussed the effects on fish and fisheries due to the flow regulation and recommended some measures to minimize adverse effects for dams. Hora (1955) also enlightened about the problems regarding the river valley projects in India with special reference to the Damodar basin. Several authors (Job and Motwani, 1952; Hora, 1955; Gopalkrishnan et al., 1966; Pantulu et al., 1966; Natarajan, 1968, 1975; Jhingran and Natarajan, 1969; Ramkrishnaiah and Banerjee, 1979; Mukherjee et al., 1986; Sarkar, 1999; Sarkar and Banerjee, 2000, 2002) studied the composition, stocking, breeding ground, seasonal effects and flood effects on fish species of Tilayia, Maithon, Konar and Panchet reservoirs and the Damodar main stream fish fauna. Pollution of the Damodar river has also been studied by several workers like Mukherjee et al. (1986), Karmakar et al. (1994), as well as by the Central Pollution Control Board (1975, 1987, 2000, 2001), Singh et al. (2003).

\section{Materials and methods}

The present study was conducted for consecutive four years $(1995,1996,1997,1998)$ during premonsoon (March to June), monsoon (July to October), and post monsoon (November to February) periods through out the entire Damodar river system. A total of 13 stations were selected for this study. Among them eight stations are related with breeding ground.

\section{Collection of Ichthyofauna}

\subsection{Fishing equipments}

Fishing gear includes gill nets, cast nets, drift nets, hand nets, hooks of all kinds, poles and lines, traps, fish fences, cutlasses and bare hands. Typical gill nets have a mesh size of $7.5 \mathrm{~mm}$. When set parallel to the shore, these nets have no harmful effect on the fishery. If set across the river, they can block upstream breeding movement and migration and capture large numbers of juvenile fishes. Cast nets have a small mesh size of $1.5-2 \mathrm{~mm}$ that can damage fish stocks through harvesting of premature juvenile fishes. Drift nets usually target breeding adults as they migrate upstream to spawn. Traps probably cause the highest mortality of these species. Fish fences catch all the species of fishes during the juvenile's migration from the streams to the main river during November and January.

\subsection{Collections of fish samples}

Site selection was made according to the gradient of the river bed in the upper valley, middle valley, lower valley and tributaries. The collection sites were selected according to the presence and absence of industries and also considering the presence of fish ladder. Each site was sampled throughout the day. Fishing was performed between 6 AM and 3 PM engaging fishermen. While sampling with gill net, it was fixed for 72 hour at the same places like upstream and downstream of Panchet, Durgapur, Ramgarh, Tori, shifted in the morning and fish removed within 24 hours (Cowx, 1983; Spindler, 1995; Allen et al., 1999; Paukert, 2004). This method was applied mainly in those areas where water depth is about $7.6 \mathrm{~cm}$ and above and also in reservoir during postmonsoon and monsoon periods. But in premonsoon when water depth is below $7.6 \mathrm{~cm}$ use of cast net, Chaba and other hand netting devices were employed.

This is to mention here that fish juveniles and oozing females caught during the collections were counted, identified in the field and released in the habitat. To avoid biasness, seining was done sufficiently in all the collection sites so that such collection could be compared with validity across the years. Repeatability of the collection is exemplified by collecting fishes in consecutive four years during three seasons from 13 stations.

\subsection{Preservation}

All the fishes captured, were counted, measured (length and weight) and grouped under two age class categories, namely, juvenile and adult following Matthews (1998). Thereafter, these were immediately segregated according to the family.

The sampled specimens were preserved in 4\% Formaldehyde in the field and brought to the laboratory of the Zoological Survey of India, Spirit Building, Kolkata for confirming species identification. The fish species was identified following standard taxonomic procedure.

\section{Hydrological parameters of water samples}

Water samples were collected from 8 study sites from where fish samples were procured. These water samples were collected during three seasons in four years (1995, 1996, 1997 and 1998) for estimation of routine hydrological parameters following standards procedures (APHA, 1995). 


\section{Results of Hydrological study}

Hydrological parameters of the river water of the Damodar, namely, $\mathrm{pH}$, dissolved oxygen, free carbon-di-oxide; methyl orange alkalinity, water and air temperature and transparency were examined from thirteen stations during 1995-1998 in premonsoon, monsoon and post monsoon.

\subsection{Tori}

$\mathrm{pH}$ in river water ranged from 6.22 to 7.5 in premonsoon 5.54 to 8.72 in monsoon and 5.3 to 9.22 in post monsoon seasons.

Dissolve oxygen in river water varied from $1.6 \mathrm{mg} / 1$ to $2.83 \mathrm{mg} / \mathrm{l}$ in premonsoon seasons. Its value varied from $1.5 \mathrm{mg} / \mathrm{l}$ to $4.4 \mathrm{mg} / \mathrm{l}$ in monsoon seasons and during post monsoon seasons it varied from $4.45 \mathrm{mg} / \mathrm{l}$ to $4.85 \mathrm{mg} / \mathrm{l}$.

Free Carbon-di-oxide in river water oscillated from $31.56 \mathrm{mg} / \mathrm{l}$ to $61.68 \mathrm{mg} / \mathrm{l}$ in premonsoon seasons, its value ranged from $10.9 \mathrm{mg} / 1$ to $31 \mathrm{mg} / 1$ in monsoon seasons and during post monsoon seasons it varied from $18.21 \mathrm{mg} / 1$ to 43.46 $\mathrm{mg} / \mathrm{l}$.

Alkalinity in river water ranged from $235.5 \mathrm{mg} / 1$ to $354 \mathrm{mg} / \mathrm{l}$ in premonsoon seasons; its value varied from $90 \mathrm{mg} / 1$ to $112.85 \mathrm{mg} / \mathrm{l}$ in monsoon seasons and during post monsoon seasons it varied from $90 \mathrm{mg} / \mathrm{l}$ to $182 \mathrm{mg} / \mathrm{l}$.

Transparency in river water varied from $24.12 \mathrm{~cm}$ to $33.2 \mathrm{~cm}$ in premonsoon; its value ranged from $12.38 \mathrm{~cm}$ to 13.16 $\mathrm{cm}$ in monsoon and during post monsoon it varied from $16 \mathrm{~cm}$ to $55.65 \mathrm{~cm}$.

Temperature in air is characteristically higher than that of the river water. In river water it ranged from $25.18^{\circ} \mathrm{C}$ to $40.2^{\circ} \mathrm{C}$ in premonsoon seasons, $16.14^{\circ} \mathrm{C}$ to $22.24^{\circ} \mathrm{C}$ in monsoon seasons, $9.88^{\circ} \mathrm{C}$ to $26.8^{\circ} \mathrm{C}$ in post monsoon seasons, whereas in air temperature ranged from $29^{\circ} \mathrm{C}$ to $42^{\circ} \mathrm{C}$ in premonsoon seasons, $19{ }^{\circ} \mathrm{C}$ to $26^{\circ} \mathrm{C}$ in monsoon seasons, 12 ${ }^{\circ} \mathrm{C}$ to $29^{\circ} \mathrm{C}$ in post monsoon seasons.

\subsection{McCluskiegunj}

$\mathrm{pH}$ in river water ranged from 5.22 to 7 in premonsoon seasons, from 7.66 to 8.72 in monsoon seasons and 5.2 to 6.8 in post monsoon seasons.

Dissolve oxygen in river water ranged from $1.85 \mathrm{mg} / \mathrm{l}$ to $2.83 \mathrm{mg} / \mathrm{l}$ in premonsoon seasons; its value varied from 1.5 $\mathrm{mg} / \mathrm{l}$ to $2.86 \mathrm{mg} / \mathrm{l}$ in monsoon seasons and during post monsoon seasons it varied from $3.65 \mathrm{mg} / \mathrm{l}$ to $6.1 \mathrm{mg} / \mathrm{l}$.

Free Carbon dioxide in river water oscillated from $9.65 \mathrm{mg} / 1$ to $21.5 \mathrm{mg} / 1$ in premonsoon seasons, its value varied from $5.21 \mathrm{mg} / 1$ to $30.2 \mathrm{mg} / 1$ in monsoon seasons and during post monsoon seasons it varied from $5.75 \mathrm{mg} / 1$ to $37.5 \mathrm{mg} / \mathrm{l}$.

Alkalinity in river water varied from $234.5 \mathrm{mg} / \mathrm{l}$ to $255 \mathrm{mg} / \mathrm{l}$ in premonsoon seasons; its value varied from $74 \mathrm{mg} / \mathrm{l}$ to $135 \mathrm{mg} / \mathrm{l}$ in monsoon seasons and during post monsoon seasons it varied from $125 \mathrm{mg} / \mathrm{l}$ to $182 \mathrm{mg} / \mathrm{l}$.

Transparency in river water varied from $28.97 \mathrm{~cm}$ to $43.4 \mathrm{~cm}$ in premonsoon, its value varied from $10.8 \mathrm{~cm}$ to $21.8 \mathrm{~cm}$ in monsoon and during post monsoon it varied from $32 \mathrm{~cm}$ to $47.7 \mathrm{~cm}$.

Temperature in air is higher than river water. In water it ranged from $33.18^{\circ} \mathrm{C}$ to $40.2{ }^{\circ} \mathrm{C}$ in premonsoon seasons, $18^{\circ} \mathrm{C}$ to $22.6^{\circ} \mathrm{C}$ in monsoon seasons, $12^{\circ} \mathrm{C}$ to $25^{\circ} \mathrm{C}$ in post monsoon seasons, whereas in air it ranged from $40^{\circ} \mathrm{C}$ to $42^{\circ} \mathrm{C}$ premonsoon seasons, $21^{\circ} \mathrm{C}$ to $26.2^{\circ} \mathrm{C}$ in monsoon seasons, $15^{\circ} \mathrm{C}$ to $28.5^{\circ} \mathrm{C}$ in post monsoon seasons.

\subsection{Ramgarh}

$\mathrm{pH}$ in river water varied from 6.3 to 6.8 in premonsoon seasons, its value ranged from 5.7 to 98.8 in monsoon seasons and during post monsoon seasons it varied from 6.3 to 8.8 .

Dissolve oxygen in river water displayed a range from $5 \mathrm{mg} / 1$ to $5.8 \mathrm{mg} / \mathrm{l}$ in premonsoon seasons, from $4.9 \mathrm{mg} / \mathrm{l}$ to 5 $\mathrm{mg} / \mathrm{l}$ in monsoon seasons and from $6 \mathrm{mg} / \mathrm{l}$ to $7.8 \mathrm{mg} / 1$ in post monsoon season.

Free Carbon dioxide in river water oscillated from $6 \mathrm{mg} / 1$ to $19.6 \mathrm{mg} / \mathrm{l}$ in premonsoon seasons; its value ranged from 7.9 $\mathrm{mg} / \mathrm{l}$ to $17.2 \mathrm{mg} / \mathrm{l}$ in monsoon seasons and during post monsoon seasons it varied from $17 \mathrm{mg} / \mathrm{l}$ to $27 \mathrm{mg} / \mathrm{l}$.

Alkalinity in river water ranged from $110 \mathrm{mg} / 1$ to $454 \mathrm{mg} / \mathrm{l}$ in premonsoon seasons, its value ranged from $7.15 \mathrm{mg} / 1$ to $159 \mathrm{mg} / \mathrm{l}$ in monsoon seasons and during post monsoon seasons it varied from $143 \mathrm{mg} / \mathrm{l}$ to $310 \mathrm{mg} / \mathrm{l}$.

Transparency in river water during the years 1995 to 1998 varied from $5 \mathrm{~cm}$ to $36 \mathrm{~cm}$ in premonsoon, its value ranged from $10 \mathrm{~cm}$ to $26 \mathrm{~cm}$ in monsoon and during post monsoon it varied from $42 \mathrm{~cm}$ to $86 \mathrm{~cm}$

Temperature in air is higher than river water. In water it ranged from $33^{\circ} \mathrm{C}$ to $37^{\circ} \mathrm{C}$ in premonsoon seasons, $22{ }^{\circ} \mathrm{C}$ to 30 ${ }^{\circ} \mathrm{C}$ in monsoon seasons, $13^{\circ} \mathrm{C}$ to $25{ }^{\circ} \mathrm{C}$ in post monsoon seasons. Whereas in air it ranged from $33{ }^{\circ} \mathrm{C}$ to $37^{\circ} \mathrm{C}$ in premonsoon seasons, $23{ }^{\circ} \mathrm{C}$ to $29^{\circ} \mathrm{C}$ in monsoon seasons and $14{ }^{\circ} \mathrm{C}$ to $26^{\circ} \mathrm{C}$ in post monsoon seasons. 


\subsection{Rajarappa}

$\mathrm{pH}$ in river water varied from 6.5 to 6.98 in premonsoon seasons, its value ranged from 6.55 to 9.36 in monsoon seasons and during post monsoon seasons it varied from 7.35 to 8.46 .

Dissolve oxygen in river water displayed a range from $2.12 \mathrm{mg} / 1$ to $4.7 \mathrm{mg} / 1 \mathrm{in}$ premonsoon seasons, from $2.3 \mathrm{mg} / 1$ to $3.46 \mathrm{mg} / \mathrm{l}$ in monsoon seasons, from $2.05 \mathrm{mg} / 1$ to $6.13 \mathrm{mg} / \mathrm{l}$, in post monsoon seasons.

Free Carbon dioxide in river water oscillated from $12.1 \mathrm{mg} / 1$ to $39.14 \mathrm{mg} / \mathrm{l}$ in premonsoon seasons, its value ranged from $9.02 \mathrm{mg} / 1$ to $34 \mathrm{mg} / 1$ in monsoon seasons and during post monsoon seasons it varied from $2.32 \mathrm{mg} / 1$ to $32.38 \mathrm{mg} / 1$.

Alkalinity in river water varied from $19 \mathrm{mg} / 1$ to $41.5 \mathrm{mg} / \mathrm{l}$ in premonsoon seasons, its value ranged from $7.15 \mathrm{mg} / 1$ to 27 $\mathrm{mg} / \mathrm{l}$ in monsoon seasons and during post monsoon seasons it varied from $8.24 \mathrm{mg} / 1$ to $30.75 \mathrm{mg} / 1$.

Transparency in river water varied from $1.12 \mathrm{~cm}$ to $5.94 \mathrm{~cm}$ in premonsoon, its value ranged from $1.42 \mathrm{~cm}$ to $5.9 \mathrm{~cm}$ in monsoon and during post monsoon it ranged from $1.58 \mathrm{~cm}$ to $5.77 \mathrm{~cm}$.

Temperature in air is characteristically higher than that in river water. It ranged from $35.14^{\circ} \mathrm{C}$ to $43.56{ }^{\circ} \mathrm{C}$ in premonsoon seasons, $26.08^{\circ} \mathrm{C}$ to $32.6^{\circ} \mathrm{C}$ in monsoon seasons, and $13.16^{\circ} \mathrm{C}$ to $32.48{ }^{\circ} \mathrm{C}$ in post monsoon seasons in air. Whereas in water it ranged between $33.26^{\circ} \mathrm{C}$ to $42^{\circ} \mathrm{C}$ in premonsoon seasons, $25^{\circ} \mathrm{C}$ to $31.06^{\circ} \mathrm{C}$ in monsoon seasons, $12.6^{\circ} \mathrm{C}$ to $29.7^{\circ} \mathrm{C}$ in post monsoon seasons.

\subsection{Chandrapura}

$\mathrm{pH}$ in river water ranged from 4.3 to 7.35 in premonsoon seasons, from 5.65 to 7.45 in monsoon seasons and 6.02 to 7.15 in post monsoon seasons.

Dissolve oxygen in river water varied from $3.15 \mathrm{mg} / 1$ to $3.78 \mathrm{mg} / 1$ in premonsoon seasons, its value ranged from 2.45 $\mathrm{mg} / \mathrm{l}$ to $3.98 \mathrm{mg} / \mathrm{l}$ in monsoon seasons and during post monsoon seasons it varied from $3.8 \mathrm{mg} / 1$ to $6.55 \mathrm{mg} / \mathrm{l}$.

Free Carbon dioxide in river water oscillated from $12.06 \mathrm{mg} / 1$ to $30.1 \mathrm{mg} / \mathrm{l}$ in premonsoon seasons; its value varied from $12.1 \mathrm{mg} / 1$ to $22 \mathrm{mg} / \mathrm{l}$ in monsoon seasons and during post monsoon seasons it varied from $7.2 \mathrm{mg} / 1$ to $32.4 \mathrm{mg} / 1$.

Alkalinity in river water varied from $28 \mathrm{mg} / 1$ to $49.49 \mathrm{mg} / \mathrm{l}$ in premonsoon seasons, its value varied from $7.15 \mathrm{mg} / 1$ to $27 \mathrm{mg} / \mathrm{l}$ in monsoon seasons and during post monsoon seasons it varied from $8.24 \mathrm{mg} / 1$ to $30.75 \mathrm{mg} / 1$.

Transparency in river water varied from $1.62 \mathrm{~cm}$ to $9.05 \mathrm{~cm}$ in premonsoon, its value ranged from $16.6 \mathrm{~cm}$ to $36.1 \mathrm{~cm}$ in monsoon and during post monsoon it varied from $13.8 \mathrm{~cm}$ to $76.62 \mathrm{~cm}$.

Temperature in air is higher than that in river water except in premonsoon of 1997,1998 . It ranged from $37.28^{\circ} \mathrm{C}$ to $38.16{ }^{\circ} \mathrm{C}$ in premonsoon seasons, $28.4{ }^{\circ} \mathrm{C}$ to $32.12{ }^{\circ} \mathrm{C}$ in monsoon seasons and $26.6^{\circ} \mathrm{C}$ to $30.14{ }^{\circ} \mathrm{C}$ in post monsoon seasons in air. Whereas in water it ranged between $34.14{ }^{\circ} \mathrm{C}$ to $39.84{ }^{\circ} \mathrm{C}$ in premonsoon seasons, $25.36{ }^{\circ} \mathrm{C}$ to $30.14{ }^{\circ} \mathrm{C}$ in monsoon seasons and $22.6^{\circ} \mathrm{C}$ to $29.7^{\circ} \mathrm{C}$ in post monsoon seasons.

\subsection{Panchet}

$\mathrm{pH}$ in river water varied from 4.65 to 6.85 in premonsoon seasons, its value ranged from 3.23 to 6.67 in monsoon seasons and during post monsoon seasons it varied from 4.9 to 7.15 .

Dissolve oxygen in river water displayed a range from $5.44 \mathrm{mg} / 1$ to $6.75 \mathrm{mg} / \mathrm{l}$ in premonsoon seasons, from $4.95 \mathrm{mg} / 1$ to $5.18 \mathrm{mg} / \mathrm{l}$ in monsoon seasons, from $5.65 \mathrm{mg} / 1$ to $9.63 \mathrm{mg} / \mathrm{l}$ in post monsoon seasons.

Free Carbon-di-oxide in river water oscillated from $21.18 \mathrm{mg} / 1$ to $47.64 \mathrm{mg} / 1$ in premonsoon seasons; its value varied from $17.5 \mathrm{mg} / 1$ to $24.5 \mathrm{mg} / 1$ in monsoon seasons and during post monsoon seasons it varied from $6.24 \mathrm{mg} / 1$ to 37.6 $\mathrm{mg} / \mathrm{l}$.

Alkalinity in river water varied from $230 \mathrm{mg} / \mathrm{l}$ to $632.12 \mathrm{mg} / \mathrm{l}$ in premonsoon seasons, its value varied from $120.5 \mathrm{mg} / 1$ to $205 \mathrm{mg} / \mathrm{l}$ in monsoon seasons and during post monsoon seasons it varied from $114 \mathrm{mg} / 1$ to $687 \mathrm{mg} / 1$.

Transparency in river water during the years 1995 to 1998 varied from $61.2 \mathrm{~cm}$ to $150.8 \mathrm{~cm}$ in premonsoon, its value ranged from $47.2 \mathrm{~cm}$ to $135.5 \mathrm{~cm}$ in monsoon and during post monsoon it varied from $72.15 \mathrm{~cm}$ to $115.83 \mathrm{~cm}$.

Temperature in air is higher than that in river water. It varied from $26.1^{\circ} \mathrm{C}$ to 29 in premonsoon seasons, $22^{\circ} \mathrm{C}$ to $30^{\circ} \mathrm{C}$ in monsoon seasons, $27^{\circ} \mathrm{C}$ to $29^{\circ} \mathrm{C}$ post monsoon seasons in air during the years 1995 to 1998 . Whereas in water it ranged between $23^{\circ} \mathrm{C}$ to $24.1^{\circ} \mathrm{C}$ in premonsoon seasons, $18.3^{\circ} \mathrm{C}$ to $25^{\circ} \mathrm{C}$ in monsoon seasons, $23^{\circ} \mathrm{C}$ to $26^{\circ} \mathrm{C}$ in post monsoon seasons.

\subsection{Durgapur}

$\mathrm{pH}$ in river water varied from 4.9 to 5.77 in premonsoon seasons, from 3.4 to 9.48 in monsoon seasons, 4.9 to 6.9 in post monsoon seasons. 
Dissolve oxygen in river water ranged from $5.73 \mathrm{mg} / 1$ to $7.17 \mathrm{mg} / \mathrm{l}$ in premonsoon seasons, its value varied from 5.8 $\mathrm{mg} / 1$ to $6.82 \mathrm{mg} / \mathrm{l}$ in monsoon seasons and during post monsoon seasons it varied from $7.46 \mathrm{mg} / 1$ to $9.6 \mathrm{mg} / \mathrm{l}$.

Free Carbon-di-oxide in river water oscillated from $31.56 \mathrm{mg} / 1$ to $61.68 \mathrm{mg} / 1$ in premonsoon seasons; its value varied from $10.9 \mathrm{mg} / \mathrm{l}$ to $31 \mathrm{mg} / \mathrm{l}$ in monsoon seasons and during post monsoon seasons it varied from $18.21 \mathrm{mg} / 1$ to 43.46 $\mathrm{mg} / \mathrm{l}$.

Alkalinity in river water varied from $123 \mathrm{mg} / \mathrm{l}$ to $533 \mathrm{mg} / \mathrm{l}$ in premonsoon seasons, its value ranged from $83 \mathrm{mg} / 1$ to $211 \mathrm{mg} / \mathrm{l}$ in monsoon seasons and during post monsoon seasons it varied from $123 \mathrm{mg} / \mathrm{l}$ to $270 \mathrm{mg} / \mathrm{l}$.

Transparency in river water varied from $38.85 \mathrm{~cm}$ to $134.1 \mathrm{~cm}$ in premonsoon, its value varied from $29.05 \mathrm{~cm}$ to 90.1 $\mathrm{cm}$ in monsoon and during post monsoon it varied from $33.4 \mathrm{~cm}$ to $90.1 \mathrm{~cm}$.

Temperature in air is higher than that in river water. It ranged from $35^{\circ} \mathrm{C}$ to $41^{\circ} \mathrm{C}$ in premonsoon seasons, $20^{\circ} \mathrm{C}$ to 30.1 ${ }^{\circ} \mathrm{C}$ in monsoon seasons and $20^{\circ} \mathrm{C}$ to $30^{\circ} \mathrm{C}$ in post monsoon seasons in water, whereas in air it ranged from $30.3^{\circ} \mathrm{C}$ to $42.3^{\circ} \mathrm{C}$ in premonsoon seasons $22.3{ }^{\circ} \mathrm{C}$ to $33^{\circ} \mathrm{C}$ in monsoon seasons and $22.9^{\circ} \mathrm{C}$ to $32.3^{\circ} \mathrm{C}$ in post monsoon seasons.

\subsection{Tarakeshwar}

$\mathrm{pH}$ in river water displayed a range from 4.2 to 7.95 in premonsoon seasons, from 4.02 to 7 in monsoon seasons and 4.95 to 7.78 in post monsoon seasons.

Dissolve oxygen in river water varied from $3 \mathrm{mg} / 1$ to $6.08 \mathrm{mg} / 1$ in premonsoon seasons, its value ranged from $2.64 \mathrm{mg} / 1$ to $6.35 \mathrm{mg} / \mathrm{l}$ in monsoon seasons and during post monsoon seasons it varied from $3.05 \mathrm{mg} / \mathrm{l}$ to $6.5 \mathrm{mg} / \mathrm{l}$.

Free Carbon-di-oxide in river water oscillated from $18.25 \mathrm{mg} / 1$ to $32 \mathrm{mg} / \mathrm{l}$ in premonsoon seasons, its value ranged from $11.6 \mathrm{mg} / \mathrm{l}$ to $30.05 \mathrm{mg} / \mathrm{l}$ in monsoon seasons and during post monsoon seasons it varied from $16.5 \mathrm{mg} / 1$ to $42.25 \mathrm{mg} / \mathrm{l}$.

Alkalinity in river water varied from $21.75 \mathrm{mg} / \mathrm{l}$ to $47.71 \mathrm{mg} / \mathrm{l}$ in premonsoon seasons, its value ranged from $11.6 \mathrm{mg} / \mathrm{l}$ to $42.34 \mathrm{mg} / \mathrm{l}$ in monsoon seasons and during post monsoon seasons it varied from $12.27 \mathrm{mg} / \mathrm{l}$ to $42.25 \mathrm{mg} / \mathrm{l}$.

Transparency in river water varied from $13.74 \mathrm{~cm}$ to $18.27 \mathrm{~cm}$ in premonsoon, its value ranged from $1.2 \mathrm{~cm}$ to $1.62 \mathrm{~cm}$ in monsoon and during post monsoon it varied from $13.1 \mathrm{~cm}$ to $30 \mathrm{~cm}$.

Temperature in air is higher than that in river water. It ranged from $33{ }^{\circ} \mathrm{C}$ to $36.4{ }^{\circ} \mathrm{C}$ in premonsoon seasons, $17.5^{\circ} \mathrm{C}$ to $27.5^{\circ} \mathrm{C}$ in monsoon seasons and $18.2^{\circ} \mathrm{C}$ to $21.14^{\circ} \mathrm{C}$ in post monsoon seasons in water whereas in air it ranged from $33.2^{\circ} \mathrm{C}$ to $38.04{ }^{\circ} \mathrm{C}$ in premonsoon seasons, $21^{\circ} \mathrm{C}$ to $29.18^{\circ} \mathrm{C}$ in monsoon seasons, $24.5^{\circ} \mathrm{C}$ to $32.4{ }^{\circ} \mathrm{C}$ in post monsoon seasons.

\section{Result of fish fauna}

The Damodar River is considerably diverse in fish fauna in number of species. This is quite evident from the fact that Job et al. (1952) recorded the occurrence of 89 species of fishes under 48 genera and 20 families. During the present study also 79 species of fishes belonging to 51 genera and 22 families have been recorded. The important breeding grounds of the upper valley, middle valley and lower valley are discussed with respect to the occurrence of the brood fish, juveniles, and fingerlings.

Tori (Stn.1) is the special breeding ground of brood fishes. The fishes are found in juvenile forms in these riffles and pools in almost dry river bed during the pre monsoon. The oozing females were caught by gillnet from this site during monsoon in all the study years. Not only the brood fishes, the juveniles (fingerlings) of Labeo dero, Labeo boggut, Cirrhinus mrigala, Nemacheilus sp., Esomus sp. and Lepidocephalicthys guntia were found confined within refill or pools with water depth of $1.5 \mathrm{~m}$ during summer. In post monsoon inside the weeds, spawn and fingerlings of Esomus danricus, Barilius bendilisis are found. But Cirrhinus reba, Brachydanio rario is found in all seasons in all the stages throughout the study period. Parluciosoma daniconius is found only in adult form. Large oozing females and matured males of Crossocheilus latius latius are found in the postmonsoon seasons but spawns and fingerlings are found in McCluskieganj. Three species of Nemacheilus have been recorded at this station. The oozing female of Nemacheilus are found in the refills during post monsoon $(1996,1997,1998)$ indicates that this rocky loach increases its population in these refills. Rhinomugil corsula male and female with matured ovary was observed during premonsoon and spawns are found in early monsoon but fingerlings were not observed. Macrognathus pancalus, Mastacembelus armatus male and female are found during postmonsoon.

At McCluskieganj (Stn.2) 17 species of fishes were recorded during the study period. Out of these Lepidocephalicthys guntia was found to be most abundant species and of all stages of lifecycle. Here, Macrognathus pancalus, Cirrhinus reba, were found during the summer, in shallow water flow in thick population but very rare during monsoon and post monsoon period. At McCluskieganj adult forms of the fingerlings and the spawns of almost all the fishes found in this particular stretch were observed in late postmonsoon and early premonsoon season. During heavy monsoon flow only adult forms are recorded except Cirrhinus reba, Mastacembelus armatus, Amblypharyngodon mola, Barilius bendilisis they are found in all seasons in all forms. Fingerlings of Brachydanio rario, Danio acquipinnatus Parluciosoma 
daniconius are recorded once during monsoon but due to flooded condition, collection was difficult during 1996 and 1998.

At Ramgarh (Stn. 3) the river bed is sandy and rocky. The sewage outlet of Central Coalfield Limited directly falls in the river near over bridge. About $5 \mathrm{~km}$ upstream of Ramgarh bridge, there is a fish ladder and above the ladder there is a pool like area with about $6 \mathrm{~m}$ depth. The oozing females and spawns and juveniles of almost all those fishes that were collected from this river stretch were found in that pool during early monsoon and postmonsoon seasons throughout the study period. It is a good breeding ground in the upper valley (Sarkar and Banerjee, 2000). This region was found to house 36 fish species and the most abundant was Garra annandeli. Chagunius chagunio and Garra sp. breeds and completes its lifecycle at this site only because starting from oozing female the seeds as well as fingerlings are only found in this region. Ramgarh has high turbidity of water and the Mystus species with oozing female and fingerlings are observed. Four species of Puntius, namely, P. chola, P. sophore, P. sarana and P. ticto were observed at Ramgarh along downstream with oozing females. Out of these, the last two species were considerably abundant in this site.

At Rajarappa (Stn.4) only 19 species of fishes were found and most abundant species was Cirrhinus reba. Large fishes like Notopterus notopterus (Total Length $58 \mathrm{~cm}$ ) and Labeo rohita $(\mathrm{TL} 68 \mathrm{~cm}$ ) were found in all the three seasons but no fingerlings of these species were observed. This may be due to the reason that the fingerlings are more susceptible to pollution and the site shows very low oxygen content $(2.05-6.25 \mathrm{mg} / \mathrm{l})$ and high turbid water. The situation indicates that these fishes do not breed in this site.

At Chandrapura (Stn.5) in Bhandaridaha the river bank lagoons were over flooded during high flood in monsoon and fish migration occurred from river to flood plains. Juveniles of Amblyphayngodon mola, Aspidoparia morar and Crossocheilus latius latius were observed in the rock lagoons at Bhandaridaha. At Chandrapura the river bed is about 1 $\mathrm{km}$ wide. Water flows in summer, along the left bank with a depth of $125-140 \mathrm{~cm}$ and $350 \mathrm{~cm}$ width, and along the right bank water flows with $280 \mathrm{~cm}$ depth and width of river is $465 \mathrm{~cm}$. Stagnant pools exist in the middle and near the edge of the river where large fishes and fingerlings were observed. 15 species of fishes were recorded from Chandrapura during the present study. The most abundant species was Cirrhinus reba. Glossogobius giuris giuris is found in pre-adult stages, $4 \mathrm{~km}$ downstream of Chandrapura Thermal Power Station (the survey site) at Bhandaridaha in the shallow and deep pools temporarily formed on the rocky bank, where river water floods in the monsoon and remains up to early premonsoon. Cirrhinus mrigala, Cirrhinus reba, Osteobrama cotio cotio, Puntius chola, puntius conchonius, Aspidoparia morar are found to complete their lifecycle in the slow flowing shallow water at Chandrapura. But the Chela labuca, Salmostoma phulo and Salmostoma bacaila are only found in adult forms. Oozing females and juveniles of Garra lamta (sucker fish) were found throughout the year during the entire study period, which indicates that this fish could tolerate high water temperature ranging from $34-39^{\circ} \mathrm{C}$ during the premonsoon season and can also complete their life cycle.

Panchet (Stn.6) is a large mainstream reservoir, impounded in the year 1959. The river bed below the reservoir is sandy and rocky. A hydral power station is situated below the dam. At this site species diversity of fishes were found to be 53 and most abundant species was Gudusia chapra. From this reservoir, spawn of Labeo rohita, Aorichthys aor, Cirrhinus mrigala, Cirrhinus reba and Labeo calbasu, Labeo bata were obtained in early post monsoon season. Oozing females of Mystus seenghala, Mystus cavasius, Mystus tengara, Ompok bimaculatus were recorded from all the permanent and temporary fish landing stations near the lockgates of the Panchet reservoir. Juveniles of these fishes were recorded from the head water of the reservoir as well as downstream of the reservoir.Juveniles of Labeo rohita, Aorichthys aor, Cirrhinus mrigala, Cirrhinus reba and Labeo calbasu were observed in the area where the river enters the reservoir and bordering Purulia district. This area is undisturbed and covered with forest. The juveniles of minnows like Colisa fasciatus, Colisa lalia, Aspidoparia morar, Securicula gora, were observed in the over flooded marshy lowland near the Panchet hill during the early postmonsoon. The oozing females and spawns and juveniles of almost all those fishes that were collected from this reservoir are found here.Channa orientalis, Channa punctatus, Channa striatus, Macrognathus pancalus, Mastacembelus armatus these fishes were found in large population in the water pockets along the eastern bank of the reservoir near Bachara gram after heavy monsoon every year. People collect juveniles of these fishes from these area and introduce in the village pond.

Reservoir of Durgapur barrage (Stn.7) houses a good number of fish species. The maximum species diversity of fishes was observed in this reservoir (56 species). The most abundant species was Gudusia chapra. The river bed below the dam a sandy and water remains only in deep and shallow ditches during postmonsoon season sheltering large carps. Small minnows were found in the shallow ditches. Whereas in deep pools large oozing female fishes like Labeo rohita, Mystus aor, Cirrhinus mrigala, Ompok bimaculatus and Barilius bendilisis bendilisis were trapped. Mostly these fishes could not survive because people are always engaged in catching those fishes with bamboo sticks by hitting them. Here thick populations of minnows and fish seeds are also destroyed by local people. They use mosquito nets to collect those fish seed and sell in local market. Seeds of Catla catla Labeo rohita, Aorichthys aor, Cirrhinus mrigala, Cirrhinus reba, Mystus seenghala, Mystus cavasius, Mystus tengara, Ompok bimaculatus and Labeo bata are introduced regurly in the 
reservoir from the Government rearing pond beside the reservoir. Here the siltation rate is very high and as a result several small and large islands locally called Manachar where many brood fishes and spawns and fingerlings are found at the semi stagnant water of the reservoir, those fishes are Glossogobius giuris giuris, Labeo rohita, Mystus aor, Ompok bimaculatus, Channa orientalis, Channa punctatus, Channa striatus, Macrognathus pancalus, Mastacembelus armatus. The oozing females and spawns and juveniles of almost all those fishes that were collected from this river stretch.People living in those islands rear Monopterus cuchia and Heteropneustes fossilis in cage and sell in local market. Small marshy lands inside the reservoir is the ideal breeding place of all the Puntius sp. collected from this reservoir. They are found in thick population there.

Tarakeshwar (Stn.8) is an agricultural area. Water depth is very low in this site. Here the river was found to house only 27 fish species. The most abundant species was Aoricthes aor. Oozing females spawns and fingerlings of Aoricthes aor, Xenentodon cancila are found in this region. At Tarakeshwar fingerlings of Glossogobius giuris giuris, Notopterus notopterus, Osteobrama cotio cotio, Puntius phutunio, Chela cachius, Gonialosa manmina were found during the postmonsoon seasons throughout the study period and it is also a breeding ground in the lower valley.

\section{Discussion}

In the Damodar valley drought is worse during premonsoon period. Anthropogenic modification of stream channels may act synergistically to make drought worse for fish. Surface flow is important and substantial discharge is necessary to maintain the surface flow on which most fishes depend. Because during the dry season, immigration and emigration cannot occur, reproduction is negligible and the numerical abundances of species can only decrease (Matthews, 1998). During summer, the rain fed Damodar runs through severe droughts, which decimate fish populations in stream.

Specially in the headwater area at Tori and Piparwar fishes in high concentration were able to survive for a limited period of time under the most unfavorable condition not due to the anthropogenic activity but natural drought. In the headwater area only a discrete pool remain during summer, because of seasonal drying but not due to sudden drying where brood fish takes shelter.

At Tori and McCluskieganj adult forms of the fingerlings of almost all the fishes found in this particular stretch were observed in late post monsoon and early premonsoon seasons. Moore and Gregory (1988a, 1988b) observed that fingerlings show a specific character in the lotic system they are found in the stream edge where bushes and water weeds are thick.

Though Tori is the special breeding ground of brood fish. But the number of fingerlings is less in Tori than McCluksigaunge.

The larger oozing females of Labeo dero, Labeo boggut, Cirrhinus reba, shows upward migration from McCluksigaunge breeding team and are caught by gillnet in this site during monsoon. The fish fry which can exist after the summer drought migrate to the down stream during first monsoon. Large densities of small fishes residing in shallow habitats inside the bushes are observed at McCluksigaunge. A specific character of the fingerlings that they are found in the stream edge where bushes and water weeds are thick. This phenomenon is distinct in the pre and post monsoon at McCluksigaunge and Tori. They also show a tendency to avoid the swiftest water current (Moore and Gregory 1988a, 1988b). At Rajarappa large fishes like Notopterus notopterus (Total Length $58 \mathrm{~cm}$ ) and Labeo rohita (TL $68 \mathrm{~cm}$ ) were found in all the three seasons but no fingerlings of these species were observed. This may be due to the reason that the fingerlings are more susceptible to pollution and the site shows very low oxygen content (2.05-6.25 $\mathrm{mg} / \mathrm{l})$ and high turbid water. The situation indicates that these fishes do not breed in this site.

This phenomenon is also observed in pre monsoon season at Chandapura. The river bed about $2 \mathrm{~km}$ wide and water flow along the left bank with 3.5-4 $\mathrm{ft} 35-40 \mathrm{~cm}$ depth and width on the right bank stagnant pools and shallow flow $(3-4 \mathrm{~cm})$ exist where numerous fish fingerlings are observed.

The present observation reveals that fingerlings of Rasbora sp., Amblypharyngodon sp., Macrognathus sp. and Nemacheilus sp., show a tendency to avoid the swiftest water current and take shelter in the bushes and water weeds along the river bed. The present study shows that the adjacent sites like Tori and McCluskieganj have more or less same species composition. However, number of fingerlings is less in Tori than in McCluskieganj.

At Ramgarh and Rajarappa large brood fishes were found. At Rajarappa only large fishes were found but not a single fingerlings was observed. But in Ramgarh the deep pools is the upstream of fish ladder houses fish fry as well as brood fishes. The large fish tries to complete their life cycle in the deep pools (Scholler 1995) said the same.

The good breeding rate of Puntius species at Ramgarh indicates that they need somewhat lentic ecosystem to breed and prefer muddy, Rocky River bed which is congenial to them at this site.

Oozing females of Puntius conchonius is found in Chandrapura, Tarakeshwar and Panchet in the mainstream. Oozing females of Puntius sophore is found in Durgapur, Panchet and Rajarappa. Fingerlings of Puntius sarana is found in the upper valley in Ramgarh and Rajarappa. 
In lotic system extensive netting may also produce some gap in the observed and actual data but the deviation is least in lentic systems. In the long term sampling where species disappears, there is often one or more anthropogenic effects that can be linked to the declines (Burr, 1991).

The seasonal variation of fishes indicates a rapid increase in availability in the monsoon and post monsoon seasons. This is because of the over flooded condition of river bed and migration of the species from the river to flood plain inside the crop fields and shallow low lands on the bank. This increases the aggregation of fish spawns by number and diversity in partial stagnant water.

However, during drought period most of the fishes take shelter in the small pools which ultimately become disconnected from the main stream. Each major disconnected pool seems to retain more or less its population of fish plus the riffle species. These fishes are crowded for weeks or months, if excessive decomposition does not develop (which lowers $\mathrm{pH}$ ) or if the pool does not dry up(lowers transparency). The fries and spawns become confined in the refills. The pools water becomes acidic at Tori during premonsoon 1998(value-6.16), Dissolve Oxygen (1.6 mg/1), Free Carbondioxide $(9.58 \mathrm{mg} / \mathrm{l})$ and high alkalinity $(245.7 \mathrm{mg} / \mathrm{l})$. It needs mention here that several workers like Starrett ( 1951), Canton et al. (1984), Moore and Georgy, (1988a,1988b) and Angelo et al.(1995), reviewed the effects of late summer reduction in stream flow on fishes emphasizing their crowding and fingerlings crowd in shallow stagnant pools. The present observation in the Damodar River, as stated above, corroborate their findings. The upper level shows $4 \mathrm{mg} / 1$ or 5-6 mg/l dissolved oxygen (DO) in average while the lower water showing 0-1 mg/l (DO) (results of hydrology). Difference of temperature to the extent of $5^{\circ} \mathrm{C}$ from upper to lower levels of water in these pools is also observed.

Mastacembelus sp. was sharply reduced in number during drought condition. During the premonsoon Tori and McClukskieganj suffer from scorching heat and the Damodar water flow almost dries up. Small scattered pools remain in the river bed where water remains very low and submerged vegetation could only be seen. In those pools spawn of Cirrhinus reba, Perluciosoma daniconius and Barilius sp. take shelter under damp slime of the drying pools in almost unswimable condition for weeks. Therefore huge number of those fishes with oozing females, fingerlings, crowd into refuge pools where hydrology of water is not within the tolerance limit (results of hydrology) and fishes has to wait until next rain. But, as the river bed dries up gradually within mid summer and water remains only in shallow water bodies, the spawns may die. The same scenario was observed in McCluskieganj. The composition of premonsoon fishes includes only young ones and fry.

Though anthropogenic changes has disturbed the natura ecosystem of this river a lot. However, astonishingly no significant difference occurred in faunal composition in these two regions during low water flow in premonsoon. In the headwater area only discrete pools remain during summer, because of seasonal drying but not due to sudden drying. The middle and the lower valley also shows no drastic effect on occurrence of fishes. The Natural breeding grounds do exists in nature.

\section{References}

Ahamad, A and Alfasane, M. A. (2004a). Primary productivity phytoplankton at Dhaka. J. Asiat. Soc. Bangladesh, Sci., 18: 47-51.

Ahmed, A. (2004).Ecological Studies of the River Padma at Mawa Ghat, Munshiganj Pakistan Journal of Biological Sciences 7 (11): 1865-1869.

American Public Health Association. (1995). Standard Methods for the examination of Water and Waste water.19 th Edition.

Angelo, A., Agostinho and Zalewski, M. (1995). The dependence of fish community structure and dynamics on flood plain and riparian ecotone zone in Parana River, Brazil. Hydrobiologia, 303: 141-148.

Angermeier, P. L., and Schlosser, I. J. (1991). Species-area relationships in stream fishes. Ecology, 70: 1450-1462.

Angermeier, P. L. and Winston, M. R. (1998). Local vs. regional influenceson local diversity in stream fish communties of Virginia. Ecology, 79: 911-927.

Anning W. D. (2004). Effects of natural and human factors on stream water quality in central Arizona. Arizona Water resource supplement. U.S.Geological Survey. Central Arizona basins National water quality Assessment programme.

Banerjee, A. K. (1972). West Bengal District Gazzetter. 26281:1-639.

Banerjee, R.K. (1988) "Man-induced environmental deterioration in the Damodar river system" Bull. Cent. Inland Capture Fish. Res.Inst Barrackpore, (57): 91-92.

Banerjee.R., K.,Mukhopadhyay, R. K., Karmakar, H. C., Chatterjee, S. K. (1994). Appraisal of the quantum and nature of effluxion into the river Damodar.J. Inland Fish. Soc. India, 26 (2):33-38. 
Banerjee, B. K. (1996). Disaster management: Flood control in DVC. Indian Journal of power and river valley Development.

Burr, B. M. (1991). The fishes of Illinois: an overview of a dynamic fauna. IL. Nat. Hist. Survey Bull, 34: 417-427.

Canton, S. P., L. D.Cline, R. A.Short and J. V. Ward. (1984). The macroinvertebrates And fish of a Colorado stream during a period of fluctuating discharge. Freshwater Biol, 14: 311-16.

Central Pollution Control Board. (1975). Damodar vally Industrial and water pollution surveysAnnual Report: 1974-1975, CPCB, Ministry of Environment and Forests, Delhi.

Central Pollution Control Board. (1987). Manual for Statistical Analysis and Interpretation of water quality data. Annual Report: 1986-1987, CPCB, Ministry of Environment and Forests, Delhi.

Central Pollution Control Board. (2000). Annual Report: 1999-2000, CPCB, Ministry of Environment and Forests, Delhi.

Central Pollution Control Board. (2001). Clean Technology Options in Small Scale Industries, Parivesh: Newsletter, July, CPCB, Ministry of Environment and Forests, Delhi.

Cuffney, T. F. and J. B.Wallace. (1989). Discharge-export relationships in headwater streams, the Influence,the influence of invertebrate manipulatios and drought.J.North.Am.Benthol. Soc, 8: 331-41.

Deacon, J.E. (1961). Fish populations, following a drought, in the Neosho and Maraides Cynges River. University of Kansas Publ. Museum Nat. Hist., 13: 359-427

Gopalkrishnan, V., Pal, R.N. and Chakraborty, P.K. (1966). Observations on the breeding of major carps in Tilayia and Panchet reservoirs. Bull. Cent. Inland Fish Res.Inst. Barrackpore, No. 9: 17.

Griswold, B. L.,C. J.Edwards and L.C. Woods.III. (1982). Recolonization of macro invertebrates and fish in an channelized stream after a drought. Ohio J. Sci., 82: 96-102.

Grossman, G. D., R. E. Ratajczak, Jr., M. Crawford and M. C. Freeman. (1998). Assemblage organization in stream fishes: effects of environmental variation and interspecific interactions.Ecological Monographs, 68:395-420.

Hauer, Ch. and Habersack, H. (2005). Diversity of flow requirements on fish habitats and interaction with river morphology. Geophysical Research, pp.156.

Hora, S. L. (1937). Comparison of the Fish Fauna of Northern and Southern Faces of the Great Himalayan Region. Record of Indian Museum, 39:1-250.

Hora, S. L. (1939). The Game Fishes of India. VIII The Mahseer and Large Scale Barbels of India. I. The Putitor Mahseer, Barbus Tor putitora (Hamilton). Journal of Bombay Natural History Soc., 41(2): 272-285.

Hora, S. L. and Nair, K. K. (1940). Further observation on bionomics and fisheries of Indian Sads Hilsa ilisha in Bengal waters. Rec. Indian Mus., 42: 35-50.

Hora, S. L. (1947). Tiesta Dam project and its likely effects on the fisheries of river. Cent. Board. Irri. Jour., 4 (8):1-58.

Hora, S. L. (1949). Satpura Hypothesis of the Distribution of the Malayan Fauna and Flora to Peninsular India. Proc. Nat. Inst. Sci. India, 15: 309-314.

Hora, S. L. (1955). Fishery problems of river valley projects in India with special reference to Damodar river basin. Irrig. And Power J., 12: 63-68.

Jhingran V.G. and Natarajan A,V. (1969). An assessment of fisheries of Damodar Valley Corporation reservoirs in relation to stocking. Proc. Seminar on the ecology and Fisheries of freshwater reservoirs, 429-456.

Job, T. J., A. David and M.P.Motwani. (1952). Observations on the Fish and Fisheries of the Damodar basin with reference to the multipurpose projects of the valley. The Journal of the Asiatic society, Science, vol. XVIII, No 2.:147-207.

Karmakar, H. C., Banerjee, R.K., Pandit, P.K. (1994). Statistical Identification of prime factor affecting Phytoplankton Population in the river Damodar. J.Indian Fish. Soc. India, 26 (2):24-27.

Larimore, R.W., W.F. Childers and C. Heckrotte. (1959). Destruction and reestablishment of stream fish and invertebrates affected by drought. Trans. Am. Fish. Soc., 88: 261-85.

Matthews,W.J., M. E. Power and A.J.Stewart. (1986). Depth distribution of Campostoma grazing Scars in an Ozark stream. Environ. Biol.Fish., 17: 291-97.

Matthews, W.J. (1986b). Fish faunal 'breaks' and stream order in the eastern and central United States. Environ. Biol. Fish, 17: 81-92.

Matthews, W.J., A.J. Stewart, and M.E. Power. (1987). Grazing fishes as components of North American stream 
ecosystems: effects of Campostoma anomalum,in Community and Evolutionary Ecology of North American Stream Fishes (eds.W.J.Matthews and D.C.Heins ). University of Oklahoma Press, Norman.: 128-35.

Matthews, W.J. (1987a). Physicochemical tolerance and selectivity of stream fishes as related to their geographical ranges and local distributions, in Community and Evolutionary Ecology of North American Stream Fishes ( eds. W.L. Matthews and D.C. Heins) University.

Matthews, W.J., R.C. Cashner. and F.P. Gelwick. (1988a). Stability and persistence of fish faunas and assemblahes in three Midwestern streams. Copeia, 1988: 945-55.

Matthews, W.J. (1998). Patterns in freshwater fish ecology. Chapman and Hall.International Thomson Publishing. 756pp. of Oklahoma Press, Norman, pp. 111-20.

Moore, K.M.S. and Georgy, S.V. (1988a). Summer habitate utilization and ecology of cutthroat trout fry ( Salmo clarka) in cascade Mountain stream. Can. J. Fish. Aquuat. Sci., 45: 1921-1930.

Moore, K.M.S. and Georgy, S.V. (1988b). Respawnse of young of the year cutthroat trout to manipulation of habitat structure in small streams. Trans. am. Fish. Soc., 117: 162-170.

Mukherjee, A., Mukherjee and Banerjee, R.K.(1986). Physico chemical characters of Panchet reservoir in the context of Industrial discharge-A preliminary study.J.Inland fish Soc.India, 18: 45-51.

Natarajan, A.V. (1968). Recommendation on the developments of fisheries of the D.V.C. reservoirs -Konar and Tilayia. C.I.C.F.R.I. Barrackpore.

Natarajan, A.V. (1975). The food spectrum of trash fishes in relation to major carps in Konar and Tilayia reservoir. J.Inland Fish. Society India, Vol 7: 80.

Nechay, B.R. (1975). Action of mercury on renal sodium transport and adenosine triphosphates activity. In zn. Miller. N.W. and T.W. Clarkson Ed.mercury, Mercurials and marcaptans. Spring field clarks. C. Thomas, III.

Pantulu, k., Algaraja and Bhimachar, B.S. (1966). Fisheries of D.V.C. in relation to construction of Dams. Procedings of National Instute of Science of India, Vol. 32, B, NO.5 and 6.

Poff NL. (1996). A hydrogeography of unregulated streams in the United States and an examination of scale-dependence in some hydrological descriptors. Freshwater Biology, 36: 101-121.

Poff, N. L. (1997). Landscape filters and species traits: towards mechanistic understanding and prediction in stream ecology. Journal of the North American Benthological Society, 16: 391-409.

Rabeni, C. F., Sarver, R.J., Wang., Wallace, Mark Weiland, J. T. Peterson. (1997). Biological criteria for streams of Missouri. A report to the Missouri Department of Natural Resources from the Missouri. Cooperative Fish and Wildlife Research Unit. Pp.124.

Ramkrishnaiah, M., Banerjee, B. K. (1979). A note on the breeding Carps in Tilayia Reservoir in context of stocking. J.Inland Fish. Society India, Vol. (1) June.

Sarkar, L., and Yadav, B.E. (1996). Larvivorous fishes of Western Ghats, Maharashtra: Biocontrol of Malaria. Geobios new Reports, 15 (2):137-138.

Sarkar, L. (1999). On a collection of fish from the head water of Damodar river.Rec. Zool. Surv. India, 97 (Part 2):149-154.

Sarkar. L., and Banerjee, S. (2000). Ichthyofauna of Damodar river system.Proc. Zool. Soc. Calcutta, 53 (1): $41-54$.

Sarkar. L., and Banerjee, S. (2002). Seasonal Distribution of Ichthyofauna in reservoirs of the Damodar river system. Ecology and conservation of Lakes, Reservoirs and Rivers.Vol. 1:518-541.ABD Publisher Jaipur, India.

Schiemer, F., Spindler,T., Wintersberger, H., Schneider, A and Chovance, A. (1991). Fish fry associations: Important indicators for the ecological status of large rivers.Verh.Internat.Verein. Limnol, 24: 2479-2500.

Schlosser, I. J. (1995). Critical landscape attributes that influence fish population dynamics in headwater streams. Hydrobiologia, 303: 71-81.

Scott MC, Helfman GS. (2001). Native invasions, homogenization, and the mismeasure of integrity of fish assemblages. Fisheries, 26: 6- 15.

Singh B, D., Singh and Misra. (2003). Coal science and technology. Current Science, VOL. 85. No. 12: 21.

Sioli, H. (1975). Tropical rivers as an expression of their terrestrial environment. pp. 275-288 In: F.B. Golly and E. Medina (ed.), Tropical Ecological Systems, Springer-Verlag, New York.

Starrett, W.C. (1951). Some factors affecting the abundance of minnows in the Des Moines River, lowa. Ecology, 32: 13-27. 
Table 1. Description of study sites related with breeding ground.

\begin{tabular}{|c|c|c|}
\hline Valley & $\begin{array}{l}\text { Selected Sites } \\
\qquad \text { (Stn.1-8) }\end{array}$ & Brief description \\
\hline $\begin{array}{l}\text { Upper valley } \\
\text { (Tori - Parjori) }\end{array}$ & $\begin{array}{c}\text { Tori(1) } \\
\text { McCluskieganj (2 } \\
\text {,Ramgarh(3) } \\
\text { Rajarappa (4). }\end{array}$ & $\begin{array}{l}\text { The upper valley length } 241.5 \mathrm{~km} \text {.it is rocky and with deep } \\
\text { gorge at Rajarappa, Bhandaridaha and adjacent areas. }\end{array}$ \\
\hline $\begin{array}{l}\text { Middlevalley } \\
\text { (Parjori-Ranigunj) }\end{array}$ & $\begin{array}{c}\text { Chandrapur (5) } \\
\text { Panchet (6) } \\
\text { Durgapur (7) }\end{array}$ & $\begin{array}{l}\text { A stretch of about } 105 \mathrm{~km} \text { is regarded as the middle valley. } \\
\text { The river bed is wide being about } 1.61 \mathrm{~km} \text { near Panchet dam, } \\
\text { almost covered by fine sand. }\end{array}$ \\
\hline $\begin{array}{l}\text { Lower Valley } \\
\text { Ranigunj to the confluence } \\
\text { of Hooghly }\end{array}$ & Tarakeshwar (8) & $\begin{array}{l}\text { This part of the valley is also called the trans-Damodar region. } \\
\text { Here the river has a number of distributaries of take off } \\
\text { channels on the left bank. }\end{array}$ \\
\hline
\end{tabular}

